\title{
Hydrogen Generation and Foaming during Tests in the GFPS Simulating DWPF Operations with Tank 42 Sludge and CST
}

by

D. C. Koopman

Westinghouse Savannah River Company

Savannah River Site

Aiken, South Carolina 29808

D. P. Lambert

This paper was prepared in connection with work done under the above contract number with the U.S. Department of Energy. By acceptance of this paper, the publisher and/or recipient acknowledges the U.S. Government's right to retain a nonexclusive, royalty-free license in and to any copyright covering this paper, along with the right to reproduce and to authorize others to reproduce all or part of the copyrighted paper. 
This document was prepared in conjunction with work accomplished under Contract No.

DE-AC09-96SR18500 with the U. S. Department of Energy.

\section{DISCLAIMER}

This report was prepared as an account of work sponsored by an agency of the United States Government. Neither the United States Government nor any agency thereof, nor any of their employees, makes any warranty, express or implied, or assumes any legal liability or responsibility for the accuracy, completeness, or usefulness of any information, apparatus, product or process disclosed, or represents that its use would not infringe privately owned rights. Reference herein to any specific commercial product, process or service by trade name, trademark, manufacturer, or otherwise does not necessarily constitute or imply its endorsement, recommendation, or favoring by the United States Government or any agency thereof. The views and opinions of authors expressed herein do not necessarily state or reflect those of the United States Government or any agency thereof.

This report has been reproduced directly from the best available copy.

Available for sale to the public, in paper, from: U.S. Department of Commerce, National Technical Information Service, 5285 Port Royal Road, Springfield, VA 22161, phone: (800) 553-6847, fax: (703) 605-6900

email: orders@ntis.fedworld.gov

online ordering: http://www.ntis.gov/ordering.htm

Available electronically at http://www.doe.gov/bridge

Available for a processing fee to U.S. Department of Energy and its contractors, in paper, from: U.S. Department of Energy, Office of Scientific and Technical Information, P.O. Box 62, Oak Ridge, TN 37831-0062,

phone: $(865) 576-8401$,

fax: (865)576-5728

email: reports@adonis.osti.gov 


\section{DISCLAIMER}

Portions of this document may be illegible in electronic image products. Images are produced from the best available original document. 
Westinghouse

Savannah River Company

Aiken. SC 29808
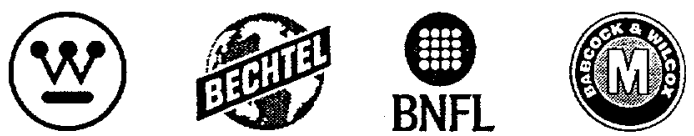

WSRC-TR-99-00302-TL, Revision 0

Keywords: DWPF, CPC, CST, Sludge, Tank 42

Retention: Permanent

September 14,1999

S. F. Piccolo, Team Leader

Salt Disposition Systems Engineering Team

\section{HYDROGEN GENERATION AND FOAMING DURING TESTS IN THE GFPS SIMULATING DWPF OPERATIONS WITH TANK 42 SLUDGE AND CST (U)}

The attached report summarizes the pilot-scale research requested by the salt disposition team to examine the effect of crystalline silicotitanate (CST) resin with adsorbed noble metals on the maximum hydrogen generation rate produced during the DWPF melter feed preparation processes (Task 13, HLW-SDT-TTR-99-13.0) ${ }^{1}$. A Task Plan was written and approved ${ }^{2}$. The product of these experiments, a melter feed, was later used in mixing, homogeneity and sampling testing which was documented in a separate report.

CST is one of the process options under evaluation as an alternative to the current In-Tank Precipitation process. CST is a non-elutable resin used to remove cesium from the supernate fraction of SRS High Level Waste. Spent CST would be combined with the sludge in the SRAT in place of the PHA that is currently part of the DWPF coupled flow sheet. Frit would then be added to the SRAT product as is typical in a DWPF SME cycle.

Testing used a non-radioactive simulant of Tank 42 sludge. A $1 / 240^{\text {th }}$ scale mockup of the DWPF process was usèd to conduct the experiments and the results were then scaled for DWPF operations. The experimental apparatus was the Glass Feed Preparation System (GFPS) installed in the SRTC Thermal Fluids Laboratory in 786-A. $110 \%$ of Tank 42 levels of noble metals and $100 \%$ Tank 42 levels of mercury were added to the starting sludge. The CST concentration was targeted to produce $10 \mathrm{wt} \%$ CST in the glass. The CST was loaded with non-radioactive cesium and noble metals ${ }^{3}$.

\section{Maior conclusions from the testing are:}

- The hydrogen generation was low throughout the experiments. In addition, no increase in hydrogen generation was caused by the addition of noble metal loaded CST. The maximum observed SRAT hydrogen generation rate was 0.0034 $\mathrm{lb} / \mathrm{hr}$ during the sludge- only run, scaled to a 6000 gallon DWPF sludge batch. The maximum occurred at the end of the SRAT reflux cycle and was about $0.5 \%$ of the current DWPF limit of $0.65 \mathrm{lb} / \mathrm{hr}$. The maximum SME hydrogen generation rate was $0.012 \mathrm{lb} / \mathrm{hr}$ based on a 6000-gallon DWPF sludge batch in the size-reduced CST run. This maximum occurred at the beginning of the SME dewater cycle and was about $5 \%$ of the current DWPF limit of $0.23 \mathrm{lb} / \mathrm{hr}$. The sizereduced CST runs produced slightly more hydrogen than the as-received CST but still far below DWPF limits.

- The size-reduced CST run produced more foam than either the sludge-only process or the as-received CST runs. However, foaming was most severe at the start of boiling in the SRAT cycle before any CST was added. Negligible foaming was noted in the three SME cycles.

${ }^{1}$ Impact of CST on Hydrogen Evolution and Foaming During DWPF Melter Feed Prep Processing, February 2, 1999, TTR Number: HLW-SDT-TTR-99-13.0.

${ }^{2}$ CST-DWPF Processing Hydrogen and Foaming, F. G. Smith, February 10, 1999, WSRC-RP-99-00229.

3 CST/Frit 202 Settling, CST Particle Size Reduction, and CST Loading, M. A. Baich, WSRC-TR-99-00244. 
- If the size-reduced CST particles are allowed to settle following upstream processing in the proposed Salt Disposition Facility, then it appears likely that they will form a solid cake that will be difficult to re-suspend for transfer into the DWPF SRAT. The carboys containing size-reduced CST in water slurry were allowed to sit unmixed for several days between the time they were filled and the time the slurry was added to the SRAT. The CST resin particles settled in the carboys and formed solid cakes. These cakes were very difficult to dislodge, breakup, and remove from the container.

If there are additional questions regarding the attached report, please contact Dan Lambert at 7-7680 or David Koopman at 77250.

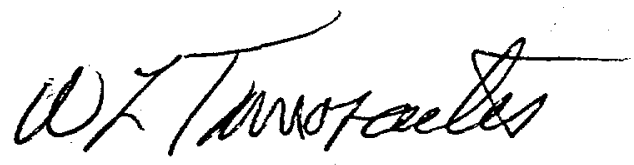

W. L. Tamosaitis, Manager

SRTC - Waste Processing Section 
WSRC-TR-99-00302, Revision 0

\section{HYDROGEN GENERATION AND FOAMING DURING TESTS IN THE GFPS SIMULATING DWPF OPERATIONS WITH TANK 42 SLUDGE AND CST (U)}

D. C. Koopman
D. P. Lambert

Westinghouse Savannah River Company

Savannah River Site

Aiken, SC 29808

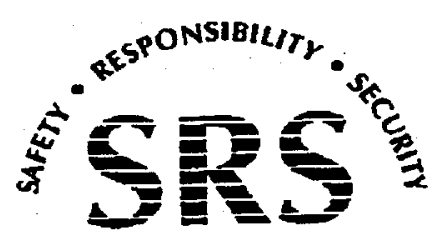

PREPARED FOR THE U.S. DEPARTMENT OF ENERGY UNDER CONTRACT NO. DE-AC09-96SR18500 


\section{DISCLAIMER}

This report was prepared by Westinghouse Savannah River Company (WSRC) for the United States Department of Energy under Contract No. DE-AC09-96SR18500 and is an account of work performed under that contract. Neither the United States Department of Energy, nor WSRC, nor any of their employees makes any warranty, expresses or implied, assumes any legal liability or responsibility for accuracy, completeness, or usefulness, of any information, apparatus, or product or process disclosed herein or represents that its use will not infringe privately owned rights. Reference herein to any specific commercial product, process, or service by trademark, name, manufacturer or otherwise does not necessarily constitute or imply endorsement, recommendation, or favoring of same by WSRC or by the United States Government or any agency thereof. The views and opinions of the authors expressed herein do not necessarily state or reflect those of the United StatesGovernment or any agency thereof. 


\section{WSRC-TR-99-00302, Revision 0}

Distribution Category: To Be Determined

Keywords: DWPF, GFPS, CST, Sludge, Tank 42

Retention: Permanent

\section{HYDROGEN GENERATION AND FOAMING DURING TESTS IN THE GFPS SIMULATING DWPF OPERATIONS WITH TANK 42 SLUDGE AND CST (U)}

D. C. Koopman

D. P. Lambert

Publication Date: September 3, 1999 
APPROVALS

Llaved Joafona

D. C. Koopman, Adthor

$\frac{9 / 7 / 99}{\text { Date }}$

$\tan y+1$

D. P. Lambert, Author

$9 / 3 / 99$

Date

7 raink/M Dmuth, II

F. G. Smith, III, Technical Reviewer

$9 / 3 / 99$

Date

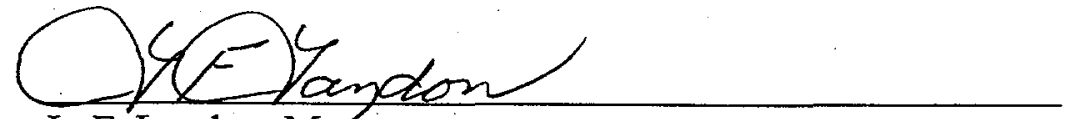

L. F. Landon, Manager

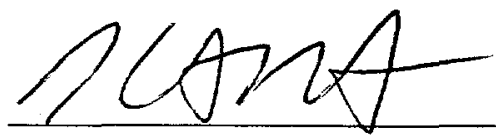

K. J. Rueter, Salt Disposition Systems Engineering Team

$\frac{9 / 3 / 99}{\text { Date }}$

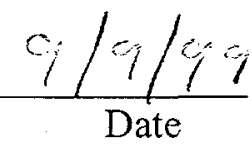

\section{WR Throradts}

W. L. Tamosaitis, Manager, Waste Processing Technology

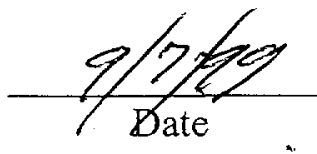

$\frac{17 \text { hats }}{\text { Jh. Carter, Manager, HLW Process Engineering }} \frac{9 / 8 / 99}{\text { Date }}$

Westinghouse Savannah River Company 


\section{EXECUTIVE SUMMARY}

The salt disposition team requested the Immobilization Technology Section to examine the effect of crystalline silicotitanate (CST) resin with adsorbed noble metals on the maximum hydrogen generation rate produced during the DWPF melter feed preparation processes (Task 13, HLWSDT-TTR-99-13.0) ${ }^{1}$. A Task Plan was written and approved ${ }^{2}$.

CST is one of the process options under evaluation as an alternative to the current In-Tank Precipitation process. CST is a non-elutable resin used to remove cesium from the supernate fraction of SRS High Level Waste. Spent CST would be combined with the sludge in the SRAT in place of the PHA that is currently part of the DWPF coupled flow sheet. Frit would then be added to the SRAT product as is typical in a DWPF SME cycle.

Testing used a non-radioactive simulant of Tank 42 sludge. A $1 / 240^{\text {th }}$ scale mockup of the DWPF process was used to conduct the experiments and the results were then scaled for DWPF operations. The experimental apparatus was the Glass Feed Preparation System (GFPS) installed in the SRTC Thermal Fluids Laboratory in 786-A. 110\% of Tank 42 levels of noble metals and $100 \%$ Tank 42 levels of mercury were added to the starting sludge. The CST concentration was targeted to produce $10 \mathrm{wt} \%$ CST in the glass. The CST was loaded with non-radioactive cesium and noble metals ${ }^{3}$.

\section{Major conclusions from the testing are:}

- The maximum observed SRAT hydrogen generation rate was $0.0034 \mathrm{lb} / \mathrm{hr}$ during the sludgeonly run, scaled to a 6000 gallon DWPF sludge batch. The maximum occurred at the end of the SRAT reflux cycle and was about $0.5 \%$ of the current DWPF limit of $0.65 \mathrm{lb} / \mathrm{hr}$. A complete listing of the hydrogen generation rates is given in Table I.

- The maximum SME hydrogen generation rate was $0.012 \mathrm{lb} / \mathrm{hr}$ based on a 6000 -gallon DWPF sludge batch in the size-reduced CST run. This maximum occurred at the beginning of the SME dewater cycle and was about $5 \%$ of the current DWPF limit of $0.23 \mathrm{lb} / \mathrm{hr}$.

Table I. Hydrogen Generation Summary for Loaded CST \& Sludge-Only Runs

\begin{tabular}{|c|c|c|c|c|}
\hline & $\begin{array}{c}\text { Sludge-Only } \\
\text { (No CST) }\end{array}$ & $\begin{array}{c}\text { As-Received } \\
\text { Loaded CST }\end{array}$ & $\begin{array}{c}\text { Size-Reduced } \\
\text { Loaded CST }\end{array}$ & $\begin{array}{c}\text { DWPF } \\
\text { Limit }\end{array}$ \\
\hline SRAT H Heak, lb/hr $^{2}$ & $\mathbf{0 . 0 0 3 4}$ & $\mathbf{0 . 0 0 1 6}$ & $\mathbf{0 . 0 0 2 7}$ & $\mathbf{0 . 6 5 0}$ \\
\hline SME $\mathrm{H}_{2}$ Peak, lb/hr & $\mathbf{0 . 0 0 6 6}$ & $\mathbf{0 . 0 0 4 1}$ & $\mathbf{0 . 0 1 2 0}$ & $\mathbf{0 . 2 2 8}$ \\
\hline
\end{tabular}

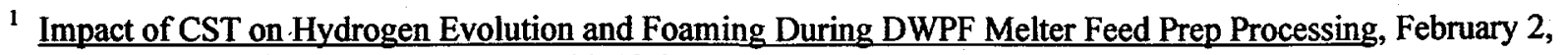
1999, TTR Number: HLW-SDT-TTR-99-13.0.

${ }^{2}$ CST-DWPF Processing Hydrogen and Foaming, F. G. Smith, February 10, 1999, WSRC-RP-99-00229.

3 CST/Frit 202 Settling, CST Particle Size Reduction, and CST Loading, M. A. Baich, WSRC-TR-99-00244. 
- The size-reduced CST runs produced slightly more hydrogen than the as-received CST but still far below DWPF limits.

- The size-reduced CST run produced more foam than either the sludge-only process or the asreceived CST runs. However, foaming was most severe at the start of boiling in the SRAT cycle before any CST was added. Negligible foaming was noted in the three SME cycles.

- If the size-reduced CST particles are allowed to settle following upstream processing in the proposed Salt Disposition Facility, then it appears likely that they will form a solid cake that will be difficult to re-suspend for transfer into the DWPF SRAT. The carboys containing size-reduced CST in water slurry were allowed to sit unmixed for several days between the time they were filled and the time the slurry was added to the SRAT. The CST resin particles settled in the carboys and formed solid cakes. These cakes were very difficult to dislodge, breakup, and remove from the container.

\section{Recommendations for Future Work:}

If CST is the selected technology, then future work should consider performing experiments to test the following:

1. Repeat the experiments with sludge and loaded CST with HM (maximum concentration levels) of noble metals and mercury in the $1 / 240^{\text {th }}$ Glass Feed Preparation System. This large-scale experiment would give a better indication of foaming and hydrogen generation problems under worst case DWPF operating conditions with boiling mass fluxes comparable to the DWPF operating value of about $50 \mathrm{lb} / \mathrm{hr}^{*} \mathrm{ft}^{2}$.

2. Further testing of the slurrying properties of size-reduced CST is recommended if that option is preferred over the as-received CST option. 
Westinghouse Savannah River Company

WSRC-TR-99-00302, Revision 0

Savannah River Technology Center

\section{TABLE OF CONTENTS}

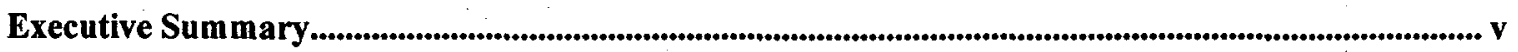

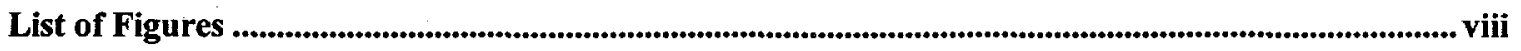

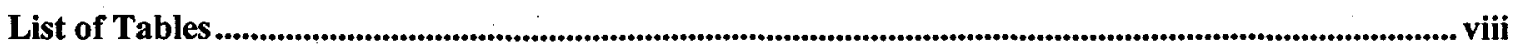

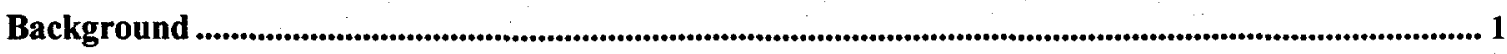

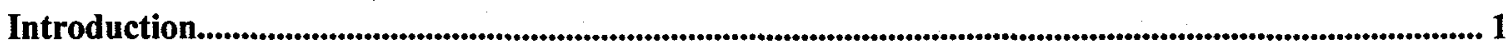

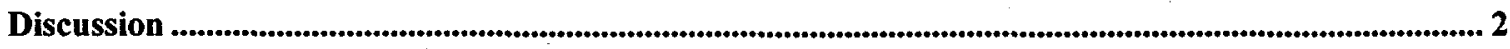

EXPERIMENTAL

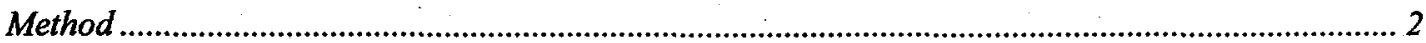

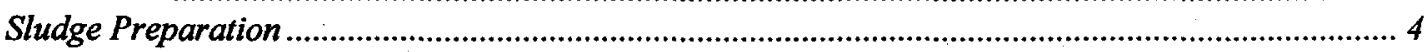

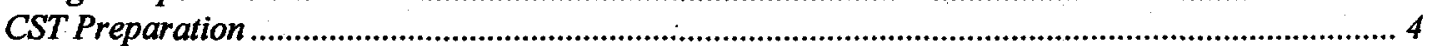

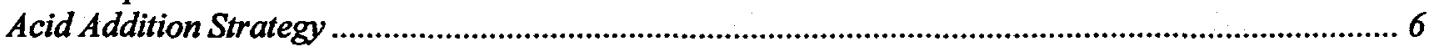

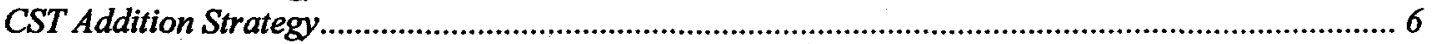

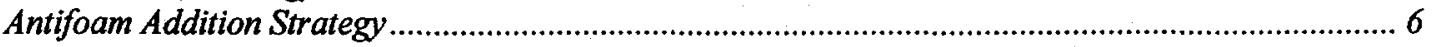

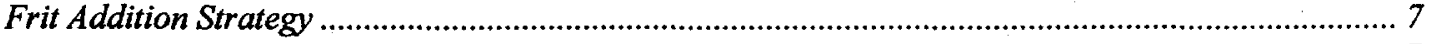

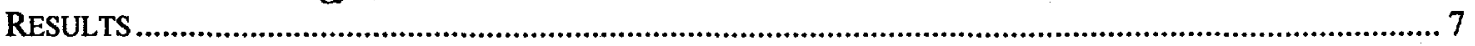

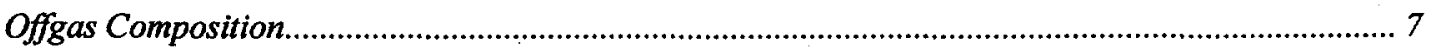

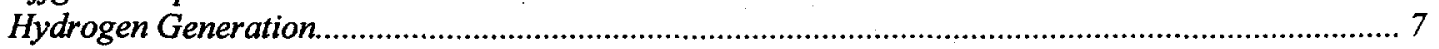

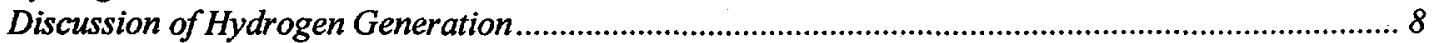

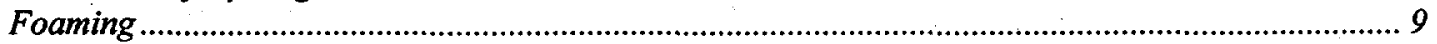

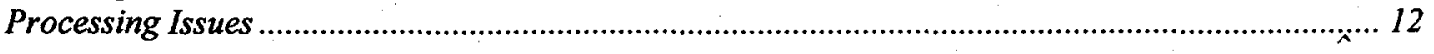

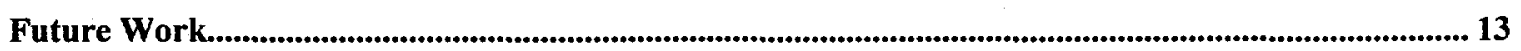

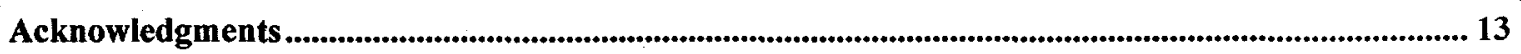

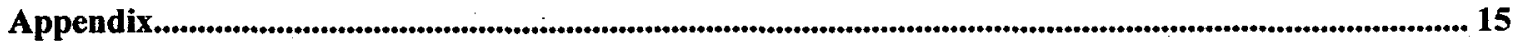




\section{LIST OF FIGURES}

Figure 1 - Hydrogen Concentration, volume \% - All Experiments.....................................9

Figure 2 - Foam Height for Experiments at Intermediate Flux (55 lb/hr) ..........................11

Figure 3 - Foam Height for Experiments at Maximum Flux $(90 \mathrm{lb} / \mathrm{hr})$..............................12

\section{LIST OF TABLES}

Table I. Hydrogen Generation Summary for Loaded CST \& Sludge-Only Runs...........v

Table II. Key Steps in the GFPS SRAT and SME Cycles...............................................

Table III. GFPS Run Summary...............................................................................

Table IV. Trim Chemical Addition to Sludge for all Experiments ......................4

Table V. CST Loading Salt Solution Makeup...............................................................

Table VI. CST Particle Size Distribution for the GFPS Tests ......................5

Table VII. Hydrogen Generation Rate for Loaded CST \& Sludge-Only Runs..................8

Table VIII. Steam flow-rate calculations for antifoam testing ..........................................10 


\section{BACKGROUND}

The Defense Waste Processing Facility, DWPF, began processing radioactive Tank 5.1 Sludge in 1996. Because of delays in the start-up of the In-Tank Precipitation (ITP) process, DWPF began sludge-only processing instead of coupled operations with sludge and salt precipitate feed as originally planned. Alternative methods of processing salt solution from high level waste are being investigated. Crystalline silicotitanate (CST) ion-exchange for the removal of cesium from salt solution is one of the process options being considered as a replacement for ITP. CST is a non-elutable resin developed by UOP that can be used to remove cesium from High Level Waste salt solutions at the Savannah River Site. The spent CST from the ion-exchange columns would be combined with washed sludge in the DWPF Sludge Receipt and Adjustment Tank (SRAT) during the SRAT cycle in place of the Precipitate Hydrolysis Aqueous (PHA) stream that is part of the current DWPF coupled flow sheet. Glass frit would be added to the SRAT product as currently practiced in the DWPF Slurry Mix Evaporator (SME) cycle.

The salt disposition team requested ITS to examine DWPF operating parameters while processing Tank 42 sludge simulant with CST resin containing adsorbed non-radioactive cesium and noble metals. In particular, the maximum hydrogen generation rate during the DWPF melter feed preparation processes and foaming in the SRAT and SME tanks were to be measured (Task 13, HLW-SDT-TTR-99-13.0).

Testing was compieted using a non-radioactive simulant of Tank 42 siudge. A $1 / 240^{\text {th }}$ pilot scale facility, the GFPS, was used for the experiments and the results were then scaled for DWPF operations. $110 \%$ Tank 42 levels of noble metals and $100 \%$ Tank 42 levels of mercury were added to the sludge. The CST concentration was targeted to produce $10 \mathrm{wt} \%$ CST in the glass. The CST resin was loaded with cesium and noble metals to reflect conditions that would be expected from the treatment of nominal SRS salt solution.

This document details the testing performed to determine the maximum hydrogen generation and foaming in the DWPF process tanks expected with a coupled flow sheet of sludge, loaded CST, and frit.

\section{INTRODUCTION}

The main objective of these tests was to measure the rate of hydrogen generation and degree of foaming in a series of experiments designed to duplicate the expected SRAT and SME processing conditions. The experiments were completed with a non-radioactive Tank 42 sludge simulant. The specific objectives of these tests were:

- Determine the maximum hydrogen generation rate during each SRAT and SME processing cycle.

- Based on the hydrogen generation rate data, determine if noble metals supported on CST resin appeared to exhibit enhanced catalytic activity over that of the same species as present in the sludge simulant. 
- Determine if any foaming problems were encountered when using the loaded CST.

- Identify any processing problems while completing SRAT/SME cycles with CST.

- Prepare melter feed for homogeneity and sampling testing.

\section{DISCUSSION}

\section{Experimental}

\section{Method}

Three pilot scale SRAT/SME processing runs were completed in the GFPS located in the SRTC Thermal Fluids Laboratory (786-A). The GFPS is a $1 / 240^{\text {th }}$-scale pilot plant built to simulate DWPF salt and chemical processing cell unit operations. The experimental setup and run plans were designed to volumetrically scale the DWPF vessels, flows, and feed-rates. For example, a 25-gallon batch of sludge simulant was equivalent to a 6000-gallon DWPF sludge batch in each of the pilot scale runs. These amounts give a scale factor of $1 / 240^{\text {th }}$ of DWPF scale based on a 6000-gallon DWPF sludge batch.

Each of the runs consisted of a typical DWPF SRAT and SME cycle. For sludge processing and chemical reaction requirements, a target acid addition of $150 \%$ stoichiometry was chosen. With the $1 / 240^{\text {th }}$ scale factor a DWPF 2-gallon/minute acid addition rate is scaled down to 31.5 $\mathrm{ml} / \mathrm{min}$. The experiments were controlled using laboratory run plans and procedures. The run plans contained the scaled conditions used for each of the experiments.

The SRAT cycle includes the key DWPF processing steps shown in Table II. The key activities in the DWPF SRAT cycle include the acid addition to the sludge, the reduction of various metals including manganese and mercury, and the destruction of nitrite. The experiments with CST also added steps in the SRAT cycle to add the CST slurry and boil off the water added with the CST. Key data to be collected during the experiments included hydrogen generation rate, foaming conditions, and any processing anomalies.

The SME cycle also includes the key DWPF processing steps shown in Table II. Key data again includes hydrogen generation rate, foaming problems, and processing issues. 
Table II. Key Steps in the GFPS SRAT and SME Cycles

\begin{tabular}{|c|c|}
\hline SRAT Cycle Steps & SME Cycle Steps \\
\hline $\begin{array}{l}\text { 1. SRAT sludge preparation, sludge } \\
\text { analysis, batching calculations. } \\
\text { 2. Heat-up to } 93^{\circ} \mathrm{C} \text {. } \\
\text { 3. Addition of nitric acid at } 93^{\circ} \mathrm{C} \text {. } \\
\text { 4. Addition of formic acid at } 93^{\circ} \mathrm{C} \text {. } \\
\text { 5. Heat to boiling, concentration down to } \\
25 \text { gallons. } \\
\text { 6. Complete first SRAT antifoam test. } \\
\text { 7. Boil off water to make room for CST. } \\
\text { 8. Cooldown, first CST slurry addition. } \\
\text { 9. Heat to boiling, complete second SRAT } \\
\text { antifoam test. } \\
\text { 10. Boil off water added with the CST. } \\
\text { 11. Complete third SRAT antifoam test. } \\
\text { 12. Cooldown, second CST slurry addition. } \\
\text { 13. Heat to boiling, complete fourth SRAT } \\
\text { antifoam test. } \\
\text { 14. Boil off water added with the CST. } \\
\text { 15. Complete fifth SRAT antifoam test. } \\
\text { 16. Add water to SRAT, complete sixth } \\
\text { SRAT antifoam test. } \\
\text { 17. Reflux for at least } 8 \text { hours to remove Hg. } \\
\text { 18. Cool down and sample. }\end{array}$ & $\begin{array}{l}\text { 1. First addition of a frit, water, } \\
\text { and formic acid to simulate } \\
\text { slurry. } \\
\text { 2. Complete first SME antifoam } \\
\text { test. } \\
\text { 3. Boil off water added with the } \\
\text { frit. } \\
\text { 4. Complete second SME } \\
\text { antifoam test. } \\
\text { 5. Second addition of a frit, } \\
\text { water, and formic acid to } \\
\text { simulate slurry. } \\
\text { 6. Complete third SME antifoam } \\
\text { test. } \\
\text { 7. Boil off water to reach a target } \\
\text { solids loading of } 45 \text { wt\% total } \\
\text { solids. } \\
\text { 8. Cool down and sample. }\end{array}$ \\
\hline
\end{tabular}

Three experimental runs were completed: one with no CST (i.e. a sludge-only run) and two with loaded CST. The first experiment was the sludge-only or no CST process, the second was with size-reduced CST particles, and the third experiment was with as-received CST particles. The three runs are summarized in Table III. All runs started with the same Tank 42 sludge simulant containing the same levels of noble metals and mercury.

Table III. GFPS CST Run Summary

\begin{tabular}{|c|l|c|l|l|c|c|}
\hline Run & Description & Sludge & $\begin{array}{l}\text { Noble } \\
\text { Metals }\end{array}$ & $\begin{array}{c}\text { CST, Loaded with } \\
\text { cesium and noble } \\
\text { metals }\end{array}$ & $\begin{array}{c}\text { Acid } \\
\text { Target }\end{array}$ & $\begin{array}{c}\text { Sludge/ } \\
\text { CST/Frit } \\
\text { Loading }\end{array}$ \\
\hline 1 & Sludge-only & Tank 42 & $\begin{array}{l}110 \% \\
\text { Tank 42 }\end{array}$ & None & $150 \%$ & $35 / 0 / 65$ \\
\hline 2 & $\begin{array}{l}\text { Sludge plus Size- } \\
\text { Reduced CST }\end{array}$ & Tank 42 & $\begin{array}{l}110 \% \\
\text { Tank 42 }\end{array}$ & Size-Reduced & $150 \%$ & $26 / 10 / 64$ \\
\hline 3 & $\begin{array}{l}\text { Sludge plus As- } \\
\text { Received CST }\end{array}$ & Tank 42 & $\begin{array}{l}110 \% \\
\text { Tank 42 }\end{array}$ & As-Received & $150 \%$ & $25 / 13 / 62$ \\
\hline
\end{tabular}


In all three runs, the nitric and formic acids were fed to the sludge-slurry in the SRAT at $93{ }^{\circ} \mathrm{C}$. For runs with CST, the first batch of loaded CST was added after the acid addition and was followed by dewatering. The second batch of loaded CST was then added followed by another dewatering step. The SRAT cycle was then continued as normal into the reflux stage. The total boiling and reflux time in the SRAT was between 10 and 12 hours to reduce the mercury concentration below $0.45 \mathrm{wt} \%$ solids and to insure nitrite destruction. The SME cycle was carried out as normal with two frit-water-formic acid additions and two dewatering steps to achieve around $45-\mathrm{wt} \%$ solids.

\section{Sludge Preparation}

The sludge simulant used in these runs contained approximately $17.1 \mathrm{wt} \%$ solids and was made to resemble the Tank 42 sludge that DWPF is currently processing. The sludge was prepared using available Tank 51 sludge-simulant, a non-radioactive simulant containing all the major sludge components. The Tank 51 simulant was chosen because its composition more closely matches the Tank 42 composition than the other available simulants. The simulant was doped with aluminum oxide, nickel nitrate hexahydrate, and manganese dioxide, since these metallic elements have significantly higher concentrations in the actual Tank 42 sludge than in the Tank 51 simulant. The noble metals and mercury were added prior to each run as listed in Table IV. Prior to the addition of noble metals, the Tank 42 simulant was analyzed for solids, elementals, total base ( $\mathrm{pH} \mathrm{5.5)}$ and density. The composition of the sludge before and after noble metal addition is summarized in Appendix A.

Table IV - Trim Chemical Addition to Sludge for all Experiments

\begin{tabular}{|l|l|}
\hline Mercuric oxide & $203.63 \mathrm{~g}$ \\
\hline Ruthenium chloride & $9.942 \mathrm{~g}(4.150 \mathrm{~g} \mathrm{Ru})$ \\
\hline Silver nitrate & $11.21 \mathrm{~g}(7.114 \mathrm{~g} \mathrm{Ag})$ \\
\hline Rhodium nitrate Solution & $20.44 \mathrm{~g}(1.008 \mathrm{~g} \mathrm{Rh})$ \\
\hline Palladium nitrate Solution & $2.718 \mathrm{~g}(0.415 \mathrm{~g} \mathrm{Pd})$ \\
\hline
\end{tabular}

\section{CST Preparation}

The CST used in these experiments was loaded with cesium and noble metals to simulate the condition of spent resin that would be processed in DWPF. About $7.5 \mathrm{~kg}$ (dry basis) of Batch 98-6 (Lot No. 999098810006) CST was loaded using 90 liters of salt solution containing Cs and noble metals in the amounts shown in Table V. After 3 days of loading in an up flow column, the $\mathrm{Cs}$ concentration in the tank had dropped to around $1 \%$ of the initial value indicating that the resin had adsorbed Cs to the expected level. At $110^{\circ} \mathrm{C}$ the weight percent solids of the un-loaded CST was determined to be $94.86 \%$. However, calcining the loaded CST at $610^{\circ} \mathrm{C}$ gave a calcined weight percent solids of $83.85 \%$ for the first batch and $85.81 \%$ for the second batch of CST. This calcine weight percent was used to calculate the amount of "air-dry" loaded CST that was added in these experiments to give $10-\mathrm{wt} \%$ CST in the glass on an oxide basis.

To produce the size-reduced CST, a special apparatus was used that pumped the CST slurry between two annular vessels until the proper size CST settled out. More details on the apparatus 
Westinghouse Savannah River Company

Savannah River Technology Center

used and the loading of the CST are contained in a separate report. ${ }^{4}$ For the size-reduced CST experiment, $6.12 \mathrm{~kg}$ of "air-dry" CST was suspended in about 31.5 liters of water. This 16.2wt\% CST slurry was contained in five 8-liter Carboys.

Table V - CST Loading Salt Solution Makeup

\begin{tabular}{|c|c|c|c|}
\hline Elements & Target Conc., ppm & $\begin{array}{c}\text { Meas. Conc., ppm } \\
\text { As-received CST }\end{array}$ & $\begin{array}{c}\text { Meas. Conc., ppm } \\
\text { Size-reduced CST }\end{array}$ \\
\hline $\mathrm{Pd}$ & 3.2 & 2.8 & 3.0 \\
\hline $\mathrm{Rh}$ & 2.1 & 1.8 & 1.9 \\
\hline $\mathrm{Ru}$ & 7.7 & 5.4 & 5.3 \\
\hline $\mathrm{Cs}$ & 1845 & 1876 & 2030 \\
\hline
\end{tabular}

Size-reduced CST was prepared as described in the report by Mark Baich ${ }^{5}$. The goal was to produce CST with a size range similar to that of frit. A particle size comparison of the sizereduced CST to the as-received CST used in the GFPS experimental work is given in Table VI.

Table VI - CST Particle Size Distribution for the GFPS Tests

\begin{tabular}{|c|c|c|}
\hline $\begin{array}{c}\text { Size Range } \\
\text { (microns) }\end{array}$ & $\begin{array}{c}\text { As-received } \\
\text { \%Chan }\end{array}$ & $\begin{array}{c}\text { Size-Reduced } \\
\text { \%Chan }\end{array}$ \\
\hline $497.8-704.0$ & 13.56 & 0.00 \\
$352.0-497.8$ & 47.20 & 0.00 \\
$248.9-352.0$ & 30.96 & 0.00 \\
$176.0-248.9$ & 5.07 & 0.00 \\
$124.5-176.0$ & 0.82 & 0.01 \\
$88.00-124.5$ & 1.87 & 0.43 \\
$62.23-88.00$ & 0.36 & 2.95 \\
$44.00-62.23$ & 0.16 & 5.78 \\
$31.11-44.00$ & 0.00 & 7.95 \\
$22.00-31.11$ & 0.00 & 7.65 \\
$15.56-22.00$ & 0.00 & 7.66 \\
$11.00-15.26$ & 0.00 & 7.19 \\
$7.778-11.00$ & 0.00 & 6.06 \\
$5.500-7.778$ & 0.00 & 6.70 \\
$3.889-5.500$ & 0.00 & 7.26 \\
$2.750-3.889$ & 0.00 & 4.61 \\
$1.945-3.889$ & 0.00 & 9.63 \\
$1.375-1.945$ & 0.00 & 11.21 \\
$0.972-1.375$ & 0.00 & 9.95 \\
$0.000-0.972$ & 0.00 & 4.96 \\
\hline Volumetric Mean & & 14.95 \\
Diameter (microns) & 382.9 & \\
\hline
\end{tabular}

${ }^{4}$ CST/Frit 202 Settling, CST Particle Size Reduction, and CST Loading, M. A. Baich, WSRC-TR-99-00244.

${ }^{5}$ CST/Frit 202 Settling, CST Particle Size Reduction, and CST Loading, M. A. Baich, WSRC-TR-99-00244. 
Samples were analyzed using the Microtrac instrument in the Analytical Development Section. The tabulated values for the size-reduced CST represent a mass-weighted average of the sample results obtained from each of the five carboys used to transport the size-reduced CST to the GFPS. The volumetric mean diameter of the as-received CST is more than 25 times larger than that of the size-reduced CST.

\section{Acid Addition Strategy}

Concentrated formic acid (90-wt \%) and nitric acid (50-wt\%) were added to acidify the sludge and complete the desired REDOX and nitrite destruction reactions. Total acid additions were based on total acid to achieve $150 \%$ stoichiometry using a scale factor of $1 / 240^{\text {th }}$ and an acid mix to produce a REDOX target of $0.2 \mathrm{Fe}^{2+} / \Sigma \mathrm{Fe}$ in the glass. 2.098 liters of $10.12 \mathrm{M}$ nitric acid and 4.650 liters of $22.99 \mathrm{M}$ formic acid were added in the SRAT cycle in each of the experiments.

\section{CST Addition Strategy}

The CST was not metered into the SRAT during boiling like PHA. It was batched in during nonboiling conditions. The size-reduced CST was added by pouring the slurry through the funnel in the top of the main process vessel. This slurry was a 16.2-wt\% slurry containing about $6.12 \mathrm{~kg}$ of "air-dry" CST, which was expected to yield $5.13 \mathrm{~kg}$ of calcined CST. The size-reduced CST slurry was also added in two steps with an intermediate dewatering step to remove slurry water. The first CST addition was about $55 \%$ of the total slurry mass, and the second CST addition was about $45 \%$ of the total slurry mass.

The as-received, loaded CST was added dry through a funnel to the main process vessel, followed by $31.16 \mathrm{~kg}$ of flush water to simulate a 20.6 -wt \% CST-water slurry. The amount of air dried CST added was $8.10 \mathrm{~kg}$ which was expected to yield $6.95 \mathrm{~kg}$ of calcined CST. This is $35 \%$ higher than the planned batching. Two partial CST additions were actually required with an intermediate dewatering step to accommodate the scaled volumes of flush water expected to be needed to slurry CST in a full-scale process. The first addition contained about $51 \%$ of the CST and $55 \%$ of the flush water. The second addition contained about $49 \%$ of the CST and $45 \%$ of the flush water.

The decision to add CST following acid addition was made based on processing issues in the GFPS SRAT vessel. If half of the CST slurry were added to the SRAT immediately following sludge and flush water addition, then it would be necessary to concentrate the SRAT prior to acid addition, i.e. at $\mathrm{pH}$ of about twelve. Historically, concentrating sludge under these conditions has been avoided because of the possibility of forming an alumina silicate gel. Consequently, the decision was made to add the acids first, concentrate down at $\mathrm{pH}$ near four, and then add the initial CST slurry.

\section{Antifoam Addition Strategy}

To determine the foaming potential of the slurry with the DWPF antifoam present, Dow Corning 544 antifoam was added per the DWPF antifoam strategy (100 ppm on a total solution basis). One part antifoam diluted with 19 parts water was added before and after acid addition and every twelve hours of operation to control foaming in the experiments. No antifoam was added outside of the planned additions during the experiments. 
Savannah River Technology Center

\section{Frit Addition Strategy}

Two equal amounts of frit, water, and formic acid were added to the SME to simulate the fritwater slurry. Frit 202 was added to the loaded CST runs since it is similar to the frit that will be used during coupled experiments. Frit 200 was used for the sludge-only experiments, since this is the frit normally used for DWPF sludge-only operations. No water was added to simulate the addition of canister decontamination water to the SME. The frit was added dry through a funnel to the GFPS main process vessel during the SME cycle, followed by 90 -weight percent formic acid, and enough water to simulate a $35-\mathrm{wt} \%$ frit slurry. The frit addition for the sludge-only run was based on a target of $65-w t \%$ frit and $35-w t \%$ sludge oxides in the glass. The frit addition for the loaded CST runs targeted a $64 \mathrm{wt}-\%$ frit, $10 \mathrm{wt}-\%$ CST oxides, and $26 \mathrm{wt}-\%$ sludge oxides glass composition.

\section{Results}

\section{Offgas Composition}

One of the main objectives of the experiments was to monitor the hydrogen generation rate. In order to calculate the hydrogen generation rate, the offgas flow and composition were measured. Since it is difficult to measure the offgas flow accurately throughout the SRAT and SME cycle, an internal helium standard was used to calculate the outlet flow. The helium and air purges were metered by using MKS mass flow controllers. The MKS mass flow controllers were calibrated prior to the runs using a MKS GRBOR Mass Flow Controller Calibrator or by the SRTC Standards Lab. In addition, flowmeters were zeroed under no flow conditions to ensure accurate readings and a leak check was performed prior to the first experiment to demonstrate that the GFPS had minimum air inleakage.

The offgas composition was monitored using a Gas Chromatograph (GC). The MTI gas chromatographs were calibrated prior to the first and third runs to ensure the measured composition of the calibration standard was within $10 \%$ of the certification concentration. A calibration check was performed before and after each experiment to ensure that the GC was still in calibration.

\section{Hydrogen Generation}

The maximum hydrogen generation during the SRAT cycle was $0.0034 \mathrm{lb} / \mathrm{hr}$ during the sludgeonly run when converted to a basis of 6000 gallons of $17-w t \%$ solids sludge. This peak occurred close to the end of the SRAT cycle reflux. This maximum SRAT hydrogen value is significantly lower than the DWPF SRAT hydrogen limit of $0.65 \mathrm{lb} / \mathrm{hr}$. The maximum hydrogen generation for the SME cycle was $0.012 \mathrm{lb} / \mathrm{hr}$ for the fine CST run which is significantly less than the DWPF SME hydrogen limit $0.23 \mathrm{lb} / \mathrm{hr}$. This hydrogen peak occurred at the start of the second SME dewatering step. It is normal to have hydrogen peaks at the onset of boiling because hydrogen tends to accumulate in the tank vapor space during non-boiling conditions (such as after cooling to add materials to the tank) due to reduced mass transfer. Note that $110 \%$ Tank 42 levels of noble metals were used in these experiments. This additional $10 \%$ is intended to account for uncertainty in the analytical measurements of sludge noble metals which can have a $\pm 10 \%$ variability. Table VII gives a complete listing of the peak hydrogen generation rates observed during the GFPS experiments. 
Savannah River Technology Center

Table VII. Hydrogen Generation Rate for Loaded CST \& Sludge-Only Runs

\begin{tabular}{|c|c|c|c|c|}
\hline & $\begin{array}{l}\text { Sludge-Only } \\
\text { (No CST) }\end{array}$ & $\begin{array}{l}\text { Size-Reduced } \\
\text { Loaded CST }\end{array}$ & $\begin{array}{l}\text { As-Received } \\
\text { Loaded CST }\end{array}$ & $\begin{array}{c}\text { DWPF } \\
\text { Limit }\end{array}$ \\
\hline SRAT GFPS $\mathrm{H}_{2}$ Peak, vol $\%$ & 0.005 & 0.004 & 0.002 & \\
\hline SRAT GFPS H ${ }_{2}$ Peak, lb/hr & 0.0034 & 0.0027 & 0.0016 & 0.650 \\
\hline SRAT Bench $\mathrm{H}_{2}$ Peak, lb/hr ${ }^{6}$ & 0.005 & 0.004 & 0.002 & 0.650 \\
\hline SRAT GFPS $\mathrm{H}_{2}$ Peak, scc/min & 1.19 & 0.95 & 0.56 & \\
\hline SME GFPS $\mathrm{H}_{2}$ Peak, vol \% & 0.020 & 0.033 & 0.012 & \\
\hline $\mathrm{SME} \mathrm{GFPS} \mathrm{H}_{2}$ Peak, lb/hr & 0.0066 & 0.012 & 0.0041 & 0.228 \\
\hline SME Bench $\mathrm{H}_{2}$ Peak, lb/hr & 0.016 & 0.010 & 0.006 & 0.228 \\
\hline SME GFPS $\mathrm{H}_{2}$ Peak, scc/min & 2.29 & 4.35 & 1.44 & \\
\hline
\end{tabular}

\section{Discussion of Hydrogen Generation}

One of the primary objectives of the testing was to determine whether the noble metals loaded onto the CST had any impact on the hydrogen generation. If the noble metals (rhodium is believed to be the active noble metal in hydrogen production) were adsorbed by the CST and were catalytically active, there may have been a large increase in hydrogen in the CST runs versus the sludge-only run. Based on analysis of the solution prepared to load noble metals on the CST, little $(<10 \%)$ rhodium was adsorbed by the $\mathrm{CST}^{7} .0 .141$ grams of Rh metalwere added to the CST solution and 1.008 grams of $\mathrm{Rh}$ was added to the sludge (seven times the possible CST noble metal). As a result, the quantity of noble metals added with the CST is less than oneseventh as much as the noble metals added with the sludge. If the adsorbed noble metals become catalytically active during loading or DWPF processing, i.e. if their active surface area is out of proportion to their mass, then the extra noble metals could cause a large increase in the hydrogen generation rate.

The hydrogen generation was low throughout all the runs (Figure I). This is due in part to the relatively low noble metal concentration in the Tank 42 sludge target. If the noble metals on the CST from salt treatment are significant in $\mathrm{H}_{2}$ generation, then it would be much easier to see that effect with a low background generation from the noble metals in the sludge. The addition of the CST appeared to have no impact on hydrogen generation. The peak in the fine CST and sludgeonly runs were both approximately 0.020 volume $\%$, excluding one higher data point $(0.033$ vol \%) at the initiation of boiling in the fine CST SME cycle. As a result, it appears that there was no increase in hydrogen generation due to the addition of the CST. The hydrogen generation for all the runs is summarized on Figure 1. Note that the peak hydrogen for all experiments is circled.

${ }^{6}$ Hydrogen Generation During Melter Feed Preparation of Tank 42 Sludge and Salt Washed Loaded CST in the Defense Waste Processing Facility (DWPF), W. E. Daniel, WSRC-TR-99-00277, Rev. 0.

7 CST/Frit 202 Settling, CST Particle Size Reduction, and CST Loading, M. A. Baich, WSRC-TR-99-00244. 
The hydrogen generation during the Coarse CST SME cycle was significantly lower than the hydrogen generation during the other two runs. Many of the readings during the SME Cycle were recorded as zero by the GC. Reanalysis of the chromatograms by Paul Monson revealed a hydrogen peak that was usually too small to quantify by the normal peak detection method ( 0.001 volume $\%$ detection limit). A post calibration check of the GC at the end of the run showed the GC was still in calibration and had no problems detecting hydrogen in the calibration gas.

The hydrogen generation during the GFPS experiments was approximately the same as was measured in 1/10,000th scale experiments (bench) at TNX. Table VII includes a comparison of the peak hydrogen generation rates during the SRAT and SME cycles for both the bench scale and GFPS experiments ${ }^{8}$.

Figure 1 - Hydrogen Concentration, volume \% - All Experiments

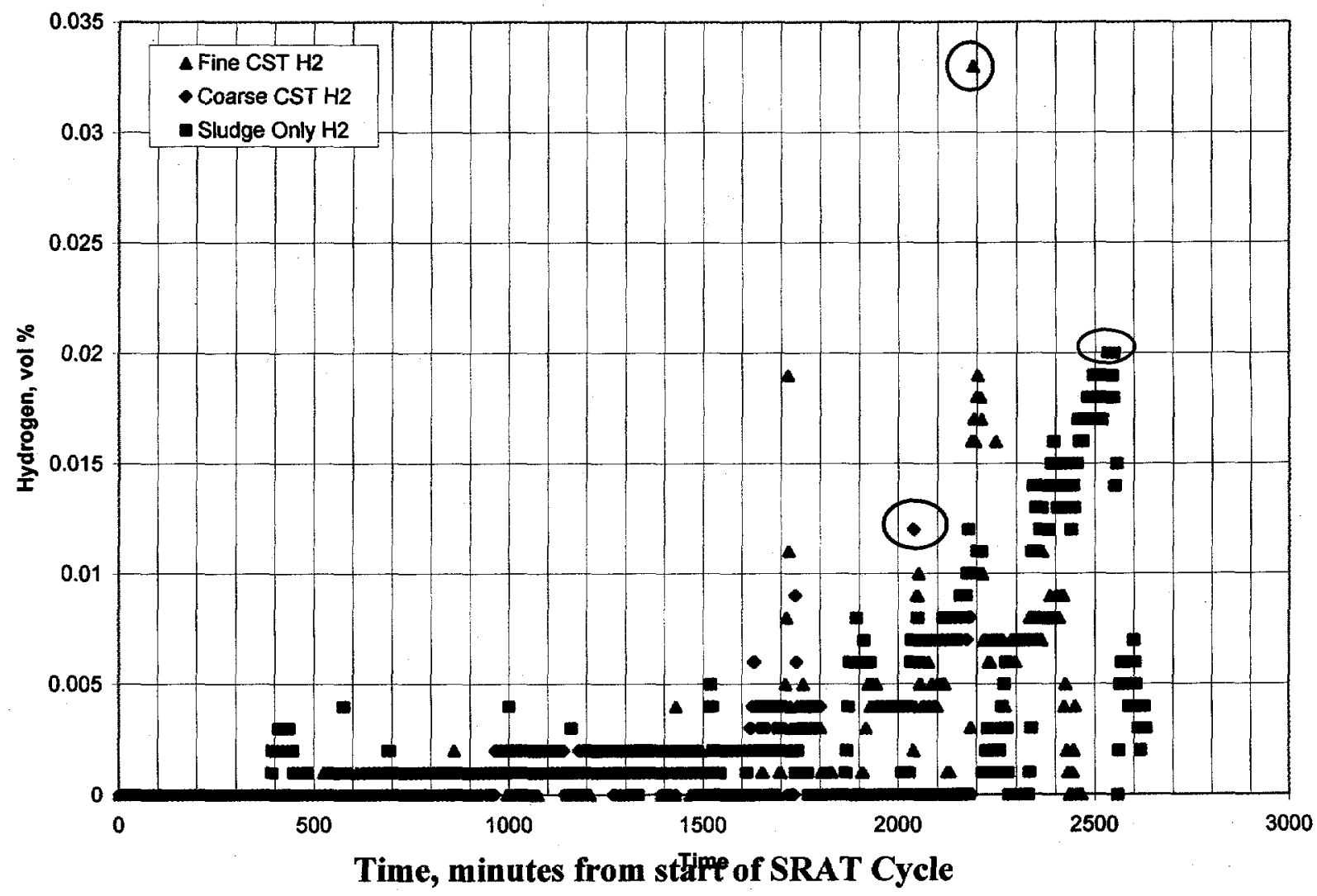

\section{Foaming}

A series of antifoam effectiveness tests was completed during the SRAT and SME cycles. The generated foam height was measured at various heat flux levels (heat flux is defined as the mass flow of water vapor per unit cross-sectional area, $\mathrm{lb} /\left(\mathrm{hr}^{*} \mathrm{ft}^{2}\right)$, of the main process vessel). The

${ }^{8}$ Hydrogen Generation During Melter Feed Preparation of Tank 42 Sludge and Salt Washed Loaded CST in the Defense Waste Processing Facility (DWPF), W. E. Daniel, WSRC-TR-99-00277, Rev. 0. 
GFPS main process vessel is heated by 50 psig steam inside a Hastelloy steam coil. The coil was designed to achieve the same maximum boiling flux at the liquid surface as the DWPF SRAT and SME steam coils (44 lb/hr- $\mathrm{ft}^{2}$ ) A steam flow-rate of $90 \mathrm{lb} / \mathrm{hr}$ to the main vessel coil is required to achieve this maximum boiling flux in the GFPS. At this flux, the boilup rate (lb/hr) is approximately four times higher in the GFPS than in DWPF. Table VIII summarizes the results of the calculated boil-up rate and boil-up flux in both DWPF and the GFPS.

The current DWPF antifoam, Dow Corning 544, was used in all three experiments. The normal DWPF antifoam strategy of adding 100 ppm before heating up, adding 100 ppm after acid additions are complete, and adding $100 \mathrm{ppm}$ after every 12 hours of processing was used. Fresh antifoam agent was added as a 1 part antifoam to 10 parts total solution. This was flushed with an equal mass of water to ensure that all of the antifoam was added to the vessel. This is equivalent to the one part antifoam to twenty parts total solution that is added by DWPF.

Table VIII - Steam flow-rate calculations for antifoam testing

\begin{tabular}{|l|l|c|c|c|}
\hline Vessel & Diameter & $\begin{array}{c}\text { Steam flow-rate, } \\
\mathrm{lb} / \mathrm{hr}\end{array}$ & $\begin{array}{c}\text { Condensate } \\
\text { Generation rate, } \mathrm{lb} / \mathrm{hr}^{*}\end{array}$ & $\begin{array}{c}\text { Condensate Flux, } \\
\mathrm{lb} / \mathrm{hr}^{-\mathrm{ft}^{2}}\end{array}$ \\
\hline DWPF & $12 \mathrm{ft}$ & $5000 \mathrm{lb} / \mathrm{hr}$ & $5000 \mathrm{lb} / \mathrm{hr}$ & $44.2 \mathrm{lb} / \mathrm{hr}-\mathrm{ft}^{2}$ \\
\hline GFPS & $18 \mathrm{in}$ & $90 \mathrm{lb} / \mathrm{hr}$ & $85(20,400 \mathrm{lb} / \mathrm{hr})$ & $48.1 \mathrm{lb} / \mathrm{hr}-\mathrm{ft}^{2}$ \\
& & $55 \mathrm{lb} / \mathrm{hr}$ & $50(12,000 \mathrm{lb} / \mathrm{hr})$ & $28.3 \mathrm{lb} / \mathrm{hr}-\mathrm{ft}^{2}$ \\
& & $25 \mathrm{lb} / \mathrm{hr}$ & $21(5040 \mathrm{lb} / \mathrm{hr})$ & $11.9 \mathrm{lb} / \mathrm{hr}-\mathrm{ft}^{2}$ \\
\hline
\end{tabular}

The antifoam effectiveness tests were performed at conditions matching the DWPF prototypical condensate generation rate $(20.83 \mathrm{lb} / \mathrm{hr}$ condensate generation rate times $240=5000 \mathrm{lb} / \mathrm{hr}-$ it takes $25 \mathrm{lb} / \mathrm{hr}$ steam flow to get this condensate generation rate, or $25 \mathrm{lb} / \mathrm{hr}$ steam supply), at an intermediate steam flow ( $55 \mathrm{lb} / \mathrm{hr}$ steam supply), and slightly above the prototypical maximum DWPF boil-up flux ( $48 \mathrm{lb} / \mathrm{hr}-\mathrm{ft}^{2}$ boil-up or $90 \mathrm{lb} / \mathrm{hr}$ steam supply). The foam tests were also performed at numerous different weight percent total solids concentrations to measure the antifoam effectiveness at different solid loadings.

In all tests, foaming was the most significant at the initiation of boiling in the SRAT cycle. At this time no CST has been added. The maximum DWPF boil-up flux could not be safely simulated in any of the experiments at this point. At steam supply rates above $55 \mathrm{lb} / \mathrm{hr}$, the foam height would have been much higher than the lid of the SRAT. Therefore, no testing was performed above $55 \mathrm{lb} / \mathrm{hr}$ during the first antifoam test of each run. The reason for the extreme foam height at this point in the process is the high generation rate of process gases $\left(\mathrm{CO}, \mathrm{CO}_{2}\right.$, $\mathrm{NO}, \mathrm{NO}_{2}, \mathrm{~N}_{2} \mathrm{O}$, etc.). This is historically also the time of for maximum foam formation in coupled (sludge and PHA) experiments.

\footnotetext{
* Numbers in parentheses are scaled to DWPF by multiplying by 240 .
} 
Figure 2 - Foam Height for Experiments at Intermediate Flux (55 lb/hr)

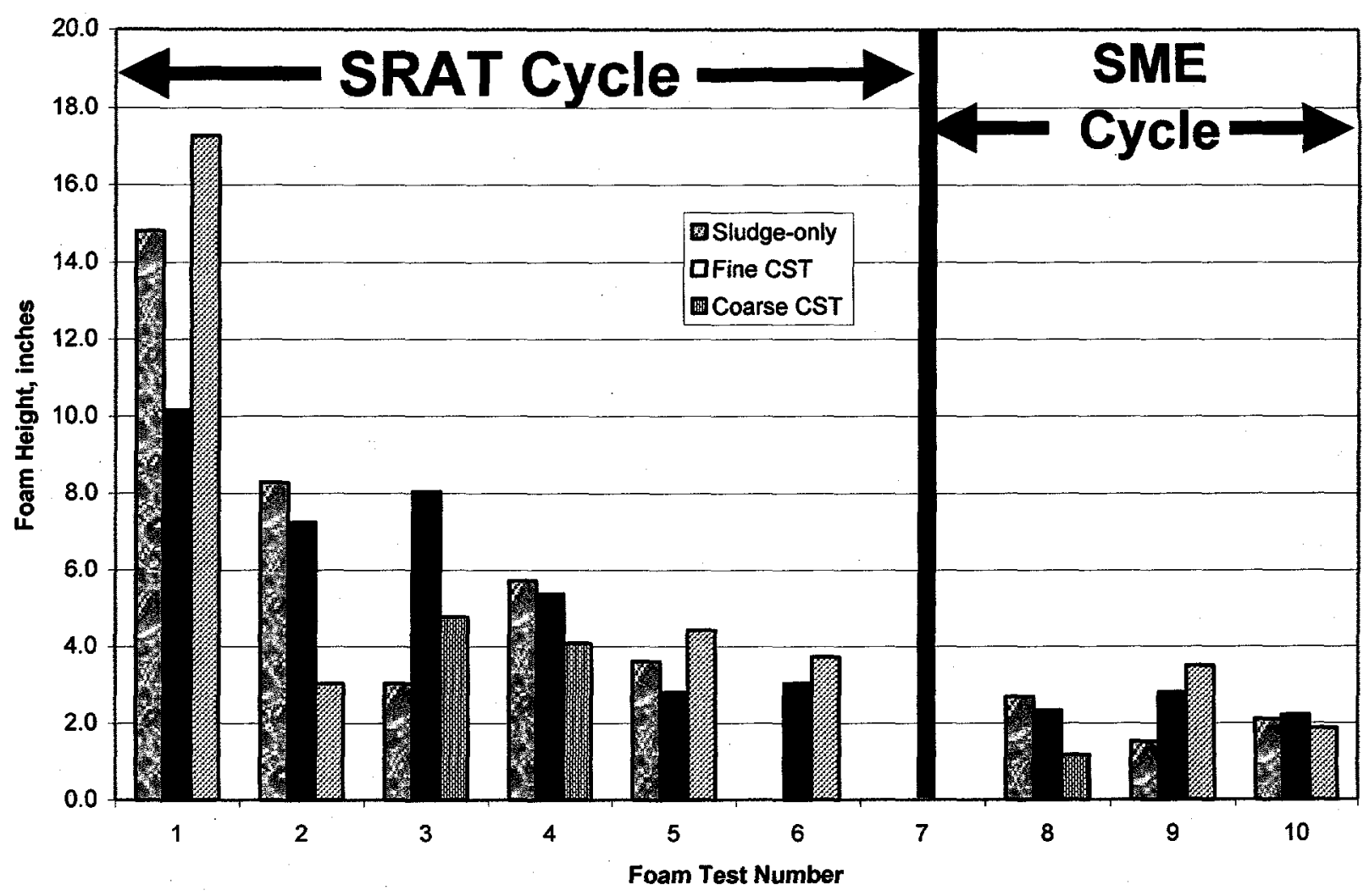

It appears that the fine CST run had more foam than either the coarse CST or sludge-only runs throughout most of the SRAT cycle (except during the first antifoam test when all were CST free). This result is not unexpected, since the fine particles in the ground CST would promote foam stabilization. None of the testing showed any significant foam formation during the SME cycle. The foam height during the antifoam experiments at the intermediate and maximum flux are included in Figures 2 and 3 respectively. 
Figure 3 - Foam Height for Experiments at Maximum Flux (90 lb/hr)

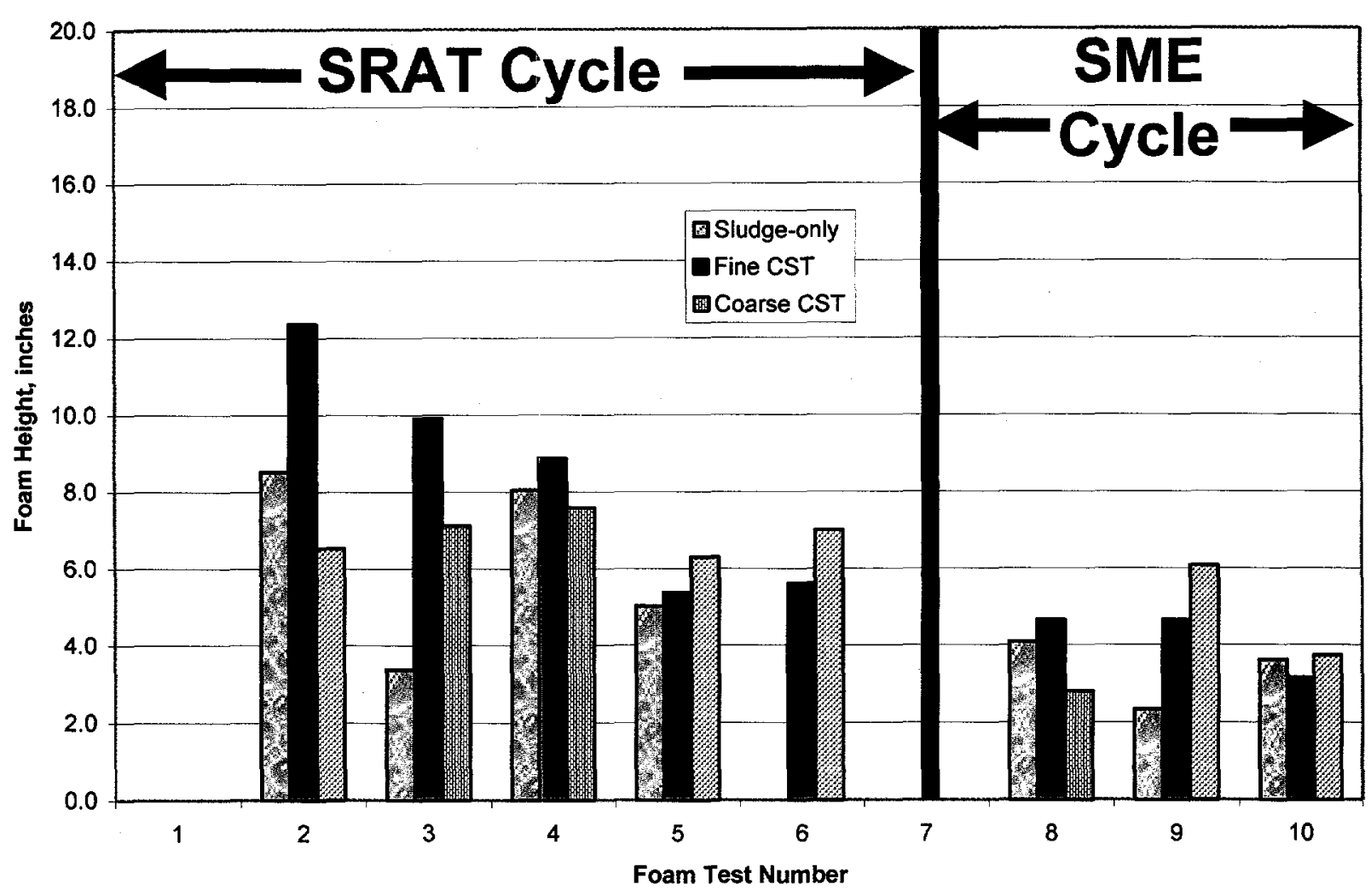

\section{Processing Issues}

Two processing issues were observed during the runs with loaded CST. First, the size-reduced CST was supplied in five 8-liter Carboys that were allowed to sit unmixed for several days between the time they were filled and the time the CST was added to the SRAT. During this time, the CST settled in the Carboys and formed solid cakes that were difficult to dislodge, breakup, and remove from the container. This observation suggests that, if size-reduced CST is used in the DWPF process, care must be taken to keep the particles suspended in the feed tank and transfer lines prior to transfers into the SRAT. If the small CST particles are allowed to settle, it appears that they will form a solid cake that will be difficult to re-suspend for transfer into the SRAT. The as-received size CST was supplied as a dry powder, so no equivalent observation could be made.

The second problem observed was a tendency for the as-received CST to settle in the SRAT and SME during processing. A significant amount of unmixed CST was observed in the bottom of the vessel below the lower agitator impeller during processing. Also, there was a zone in the vessel near the bottom impeller where the CST was observed to transition from an apparently well-mixed condition to essentially being out of solution. However, this observation is clearly a function of vessel mixing characteristics, and mixing in the GFPS is not representative of that in 
the DWPF processing vessels. The GFPS has a relatively large volume below the lower agitator compared to DWPF processing tanks, and it was in this volume that the as-received CST collected. Tank homogeneity experiments are being performed as a separate part of the CST program in a model tank that is an exact $1 / 240^{\text {th }}$-scale model of the SME. Results of those tests will more definitively indicate any tendency of the CST to settle under actual DWPF mixing conditions.

\section{FUTURE WORK}

These experiments were designed to measure hydrogen generation using loaded CST in DWPF SRAT/SME cycles with Tank 42 levels of noble metals and mercury. Earlier experiments with unloaded CST showed more hydrogen (about 40\%) than the sludge-only experiment done at the same time. In these earlier experiments, the maximum hydrogen in the SRAT was $0.41 \mathrm{lb} / \mathrm{hr}$ and the maximum hydrogen in the SME was $0.22 \mathrm{lb} / \mathrm{hr}$ on a DWPF basis. These earlier experiments were done with Tank 42 sludge but with HM (maximum concentration) levels of noble metals and mercury. The HM Tank 42 sludge from these earlier experiments had 34 times as much palladium, five times as much rhodium, nine times as much as ruthenium, and three times as much mercury as the Tank 42 sludge used in the present series of loaded CST experiments. These earlier experiments were also made with a different CST (UOP IONSIV IE-911, Lot \#999096810004, 8/3/98) which could have affected the results.

If CST is selected as the technology for further study, then, based on the current results and the earlier experimental findings, it is recommended that a bench-scale experiment using sizereduced loaded CST be performed to see the impact of HM levels of noble metals on hydrogen generation. A $1 / 240^{\text {th }}$ run should also be performed in the Glass Feed Preparation System to see how sensitive the results are to equipment scale.

\section{ACKNOWLEDGMENTS}

Thanks to Frances Williams, John DuVall, Mary Moss, Vickie Williams, Tony Burckhalter, Sammie King, Nick Odom, William Ryan, and Terri Snyder for doing an excellent job preparing for and carrying out the planned experiments. Their team approach toward work is very much appreciated. The long hours they worked to accomplish these experiments is to be commended.

Thanks to Paul Burket for his leadership in taking the QVF supplied glassware and equipment and making it a fully functional, automated pilot plant that worked very well during these experiments.

Thanks to Erich Hansen for helping us find a replacement SRAT recirculation and transfer pump when the supplied pump failed.

Thanks to Paul Monson for his help in calibrating the GC and reanalyzing the data after the experiments were complete.

Thanks to the technicians, engineers and management of the Thermal Fluids Engineering Lab. Thanks to Mark Fowley for leading the PHR process and Tim Steeper and Dan Burns for their engineering insight and support. Thanks to Jerry Corbett for planning the reconfiguration of the 
unit to allow better use of the space and allow better use of the unit. Thanks to Susan Hatcher for coordinating the various tasks in the Thermal Fluids Lab. Thanks to Vern Bush for his wiring of the electrical cabinet and thanks to Andy Foreman and Mike Armstrong for their work in the construction of the unit.

Thanks to Dave Best, Eric Frickey and Sheri Vissage for their quick analytical support and thanks to ADS for giving quick analytical support while the Mobile Lab was shutdown. 
Weśtinghouse Savannah River Company

WSRC-TR-99-00302, Revision 0

Savannah River Technology Center

Appendix A - Pre-trim Sludge-simulant Average Composition, Post-trim Sludgesimulant Expected Composition, and Targeted DWPF Sludge Composition

\begin{tabular}{|l|c|c|r|}
\hline & \multicolumn{1}{|c|}{$\begin{array}{c}\text { Pre-trim } \\
\text { Sludge }\end{array}$} & \multicolumn{1}{c|}{$\begin{array}{c}\text { Post-trim } \\
\text { Sludge }\end{array}$} & $\begin{array}{c}\text { DWPF } \\
\text { Target } \\
\text { Sludge }\end{array}$ \\
\cline { 2 - 4 } $\begin{array}{l}\text { (No Hg \& } \\
\text { Noble } \\
\text { Metals) }\end{array}$ & $\begin{array}{c}\text { (110\% Noble } \\
\text { Metals) }\end{array}$ & $\begin{array}{c}\text { (110\% Noble } \\
\text { Metals) }\end{array}$ \\
\cline { 2 - 4 } & wt-\% & wt-\% & \multicolumn{1}{c|}{ wt-\% } \\
\hline $\mathrm{Ag}$ & 0.000 & 0.040 & 0.040 \\
$\mathrm{Al}$ & 7.891 & 7.710 & 8.590 \\
\hline $\mathrm{Ba}$ & 0.006 & 0.006 & $\mathrm{n} / \mathrm{a}$ \\
$\mathrm{Ca}$ & 2.631 & 2.570 & 2.510 \\
\hline $\mathrm{Cr}$ & 0.166 & 0.162 & 0.151 \\
$\mathrm{Cu}$ & 0.064 & 0.063 & 0.042 \\
\hline $\mathrm{Fe}$ & 24.395 & 23.838 & 23.461 \\
$\mathrm{Hg}$ & 0.000 & $1.050^{\#}$ & 1.050 \\
\hline $\mathrm{K}$ & 0.157 & 0.154 & 0.234 \\
$\mathrm{Mg}$ & 1.253 & 1.225 & 1.287 \\
\hline $\mathrm{Mn}$ & 3.491 & 3.411 & 3.688 \\
$\mathrm{Na}$ & 7.349 & 7.181 & 6.835 \\
\hline $\mathrm{Ni}$ & 0.329 & 0.321 & 0.352 \\
$\mathrm{~Pb}$ & 0.139 & 0.136 & $\mathrm{n} / \mathrm{a}$ \\
\hline $\mathrm{Pd}$ & 0.000 & $0.002^{\sharp}$ & 0.002 \\
$\mathrm{Rh}$ & 0.000 & $0.006^{\#}$ & 0.006 \\
\hline $\mathrm{Ru}$ & 0.000 & $0.023^{\#}$ & 0.023 \\
$\mathrm{Si}$ & 0.916 & 0.895 & 0.987 \\
\hline $\mathrm{Sr}$ & 0.029 & 0.029 & $\mathrm{n} / \mathrm{a}$ \\
$\mathrm{Ti}$ & 0.031 & 0.030 & 0.031 \\
\hline $\mathrm{Zn}$ & 0.155 & 0.152 & $\mathrm{n} / \mathrm{a}$ \\
$\mathrm{Zr}$ & 0.058 & 0.056 & 0.069 \\
\hline & $\mathrm{n} / \mathrm{a}=$ not analyzed & \\
& & & \\
\hline & & & \\
\hline
\end{tabular}

" Calculated, not measured.

" Calculated, not measured.

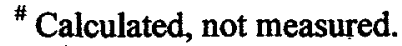

\# Calculated, not measured. 
Distribution:

L. M. Papouchado, 773-A

W. L. Tamosaitis, 773-A

K. J. Reuter, 704-3N

J. T. Carter, 704-3N

J. F. Barnes, 704-3N

L. F. Landon, 704-1T

S. L. Marra, 704-T

F. G. Smith, 704-1T

P. L. Rutland, $704-190 \mathrm{~N}$

H. H. Elder, 704-196N

R. A. Jacobs, $704-3 \mathrm{~N}$

G. A. Taylor, 704-196N

E. W. Holtzscheiter, 773-A

D. B. Burns, 786-5A

J. E. Occhipinti, 704-27S

R. E. Edwards, 704-25S

D. C. Koopman, 704-T

D. P. Lambert, 704-1T

W. E. Daniel, 704-1T

R. E. Eibling, 704-1T

M. F. Williams, 704-1T

STI, 703-43A (4) 